\title{
DOI: 10.7596/taksad.v10i4.3139
}

Citation: Mirmobini, N. \& Narani, H. S. (2021). Classification of Gurkani and Safavid Fabrics' Motifs According to the Impact of Persian Art on the Region. Journal of History Culture and Art Research, 10(4), 1-17. doi: http://dx.doi.org/10.7596/taksad.v10i4.3139

\section{Classification of Gurkani and Safavid Fabrics' Motifs According to the Impact of Persian Art on the Region}

\author{
Niaz Mirmobini ${ }^{1}$, Hanieh Sheikhi Narani ${ }^{2}$
}

\begin{abstract}
Fabrics and the use of patterns in the textile industry have undergone countless and astonishing changes due to the biological climate, the degree of civilization and culture, religious beliefs and customs. The study of the evolution of clothing and various fabrics is not only important from the point of view of history and art, but also from the point of view of sociology and understanding of the nations' psychology. The history of patterns is the same as the history of textiles and clothing, so it can be examined directly and indirectly from a conceptual and thematic point of view. Comparing the patterns and designs of Indian Gurkani fabrics with the textiles and artworks of Safavid Iran shows that Indian weavers have created works under the influence of Iranian art that is difficult to distinguish from each other. Due to the many impacts of Iranian art in many designs, the Gurkani have consciously tried to localize the used patterns and motifs, such as the altar pattern. A variety of motifs, including decorative, plant, animal, and pictorial arrays, have been used in Gurkani Indian fabrics, which have undoubtedly been greatly influenced by the Iranians according to the conditions of the time. The main purpose of this research is to classify the patterns of Safavid and Gurkani fabrics and the main focus of the research is the woven designs and patterns in Safavid and Gurkani fabrics. Accordingly, by classifying the designs and patterns, the level and extent of their impact on each other have been studied and plant, human, animal and calligraphic motifs have been studied comparatively.
\end{abstract}

Keywords: Fabric, Gurkani, Motifs, Safavid.

\footnotetext{
${ }^{1}$ Department of Art and Architecture, Faculty of Visual Art, Islamic Azad University, Science and Research Branch, Tehran, Iran. Email: Mirmobini@chmail.ir

${ }^{2}$ Department of graphic of Rasam Institute of Higher Education, Karaj, Iran. Email: h_sh_graphic@yahoo.com
} 


\section{Introduction}

Fabric weaving is one of the professions and industries that has a long and ancient history, and its history can be traced back to the written history of Iran and even earlier. The land of Iran is unique in terms of the history of weaving as well as the emergence of evolution of methods, tools and textile products in the history of nations' industries. The history of weaving and the process of its formation and how it lasts, like other industrial and artistic phenomena, has been affected by historical ups and downs. Also, the production method and patterns of each fabric are an important source for understanding the political, economic and social conditions of the society that produces it (Ruhfar 1378,2 ). Iran's geographical location and social phenomena have always made this industry not only benefit from the emerging people ideas of this land, but also the influence of different cultures of China, Egypt and Mesopotamia, which were connected through Iran, has played a major role in its development. The peak of Iranian and Indian weaving art can be seen in these two periods (Safavid and Gurkani). The general classification of patterns proves that the role of fabrics in these two periods can be divided into two groups: abstract and realistic. The types of this division can be seen in combination in relationships such as: human-plant, human-plant-animal, human-plant-animal-written, human-plant-written-abstract motifs, and by studying the samples, the most motifs to this are: plant, animal, human, geometric, written, among which the most abundance belongs to plant motifs in both periods. By examining the historical, social, cultural and artistic periods has been cleared that in addition to the use and concept of aesthetics, patterns on fabrics have an important place graphically in the composition of fabrics. In fact, today one of the arts that need to be studied extensively is the art of fabric weaving and patterns used in textiles and clothing, an art that has a long history in Iran and has accommodated various types and patterns over the centuries. In this research, the patterns of fabrics are collected and classified. The art of weaving has a long history due to the basic human need for clothing. From the use of leaves for covering, to the invention of the spinning wheel and the transformation of fabric into a means of pride and the introduction of the political, economic, social and climatic conditions of the society that produces it and becoming a ground for artists to perform, this process has gone through ups and downs and is proud that Iran is one of the pioneers of this artindustry in the world. But the post-Islamic textile art continued to grow and excel in each period with its own characteristics. But in the Safavid period, the fame and greatness of the art of Iranian textile weaving reached its peak and the existence of fabrics with various and luxurious patterns has shown it. Tourists who have traveled to Iran during this period have praised the fabrics of this period in their travelogues (Pope 1381, 2391). Therefore, in this research, we decided to examine the patterns of Safavid and Gurkani fabrics.

\section{Theoretical foundations}

Achaemenid clothes had patterns and types of flowers and leaves and their pants were embroidered with gold. The patterns and colors of the red clothes of the Eternal Shooters in the Louvre Museum in France are very beautiful examples of Achaemenid fabrics. These clothes have detailed designs; Like rectangular and eight-pointed star shapes on a yellow background and yellow, green flowers on a white background. These historical documents show that the art of weaving, as well as carpet weaving, was prevalent in Iran centuries before the Achaemenid era (Ackerman 1387, 9). The emergence of Islam was the prelude to a new era in Iran that gradually transformed the social and cultural life of the people. The clothes of the kings of the omayyad were made of the most exquisite fabrics of Khuzestan. Luxurious Iranian clothes were gradually used by the Arabs from the time of Mu'awiyah onwards (Ravandi 1341, 558). After the Umayyads, Bani Abbas came to power with the kingdom of Safah in 132 $\mathrm{AH}$. They were opponents of the omayyad. The Abbasid government moved its capital to Baghdad, the former seat of the Sassanid government, and developed as a result of the influence of Iranian culture at the court, trade and industry, especially textiles, (Baker 2006, 60). Historians have written that Mansour, the Abbasid caliph, followed Sassanid customs and traditions in worldly affairs. During this period, wearing silk and woolen or colorful silk clothes was common and silk fabrics were decorated with images of animals, flowers and plants (Chitasazan 1379, 81). The influence of Islam in the traditions of Iran was slow, so in the study of weaving of the Islamic period, many elements of Sassanid 
art can be seen (Wilson 1317, 126). In the fourth century AH, Iranian weavers made changes in fabric decorations. They left some forms and used the role of flowers and plants in textiles (Zaki 1987, 229). Determining the types of textures of this period has remained vague and it is not easy to distinguish them from each other, but the difference between the textiles of the early Islamic period and Sassanid fabrics is the details and elegance of the designs. Gradually, from the end of the third century AH, the use of calligraphy in decorations became common (Ruhfar 1378,5). The color of clothes also changed after Islam; For example, national and religious sects adorned themselves in a special color and wore black or white or red. Of which, Siahjamgan, Sorkh Jamgan and Sefid Jamgan are famous in history (Ziapour 1343, 34). Although there are no significant examples of textiles of this period but considering that other industries of that period have not changed much to separate them from the Sassanid style, it can be concluded that textile weaving has continued to work in the same Sassanid style. Therefore, weavers in this period used the margins and leaves of trees, hunting landscapes and shapes of animals and birds followed the Sassanid principles. But from the fourth century AH, weavers gradually abandoned these forms.

During this period, relations between Iran and China expanded and a number of Islamic immigrants settled in China and began to produce silk fabrics. Therefore, these goods had a great impact on the style of Islamic weaving centers and even its influence penetrated into Italian weaving factories. The texture of silk fabrics became important in Iran during this period, especially in Gilan, Khorasan, Yazd and Kerman. Silk cloth was a precious treasure at that time, and part of the city's taxes were paid in cloth. During this period, intricate geometric designs were used in the fabric weaving, which were woven with a stretching machine. One of the topics that can be seen in the textiles of the Mongol period is the prevalence of the principles of decorating fabrics with fringes (Ackerman 1387, 151). Ikat fabric was not new in Iran at this time, but in the Mongol period it was produced as a striped design. Therefore, Chinese decorative objects such as dragons and angels and other mythical animals, lotus flowers and Chinese clouds were imitated (Ackerman 1387, 152). Undoubtedly, Calico was common in Iran during the patriarchal period, because during this period, the Mongol rulers supported Chinese goods, and therefore fabrics with Chinese patterns were found abundantly in Iran. Iranian craftsmen, in order to compete with the Chinese and satisfy the Mongol masters started painting on cloth with a brush and then a pen with a mold (Yavari 1385, 15). The only means of creating highlighted samples was using gold and silver threads. The use of gold and silver threads in the production of silk fabrics is one of the prominent features of the fabrics in this period. But the use of metals as a coating of gold and silver on textiles was not common, but sometimes it was used as a thin strip. But in the late seventh century there were restrictions on the use of precious metals, especially gold thread, in textiles. In this period, the general tendency was to dark colors in the form of monochrome or two-color fabrics (Ackerman 1387, 157) (Figure 1).

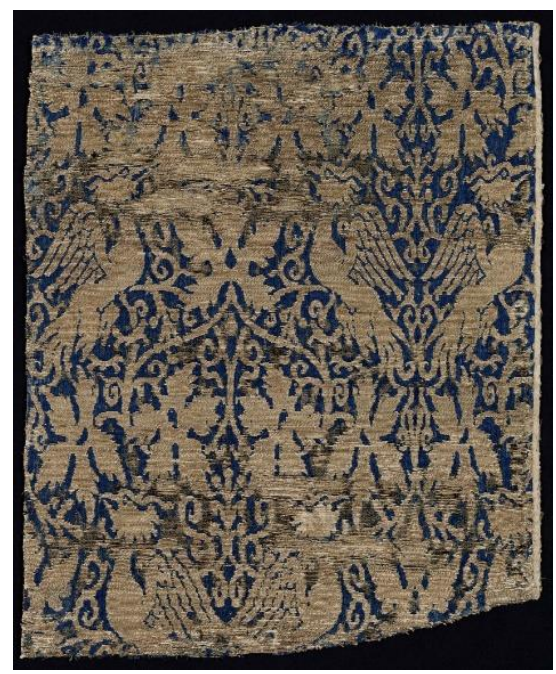

Figure 1. Silk fabric with the patterned figure of phoenix Ilkhani, Tabriz, the second half of the 14th century - 8th century AH, Boston Museum of Fine Arts (www.mfa.org) 
The golden age of Iranian weaving art coincides with the beginning of the Safavid dynasty. The art of weaving in the Safavid period not only made up for the backwardness of previous eras, but also due to the immediate support of the Safavid kings to artists, a great success of this industry was achieved. According to the writings of European tourists, this period is one of the most important periods in the Iranian weaving industry (Zaki 1987, 201). The first Safavid kings supported the textile and weaving industry as they should, Shah Ismail encouraged the production of silk and cotton fabrics, established new industrial centers, and expanded trade with Turkey, India, and China. Shah Abbas I established the weaving industry to such an extent that it supported his industry in concentrating a vast country with a scattered and disobedient population. Silkworm breeding became popular in the coastal states of the Caspian Sea, as a result of which a sufficient amount of raw silk was exported to Europe and Russia (Fariyeh 1374, 159). Towards the end of this period, incompetence and incapacitation became widespread in the Safavid state, and the attention of the kings of this dynasty to art and great artists decreased; All kinds of Safavid weavings declined and market products became popular and especially popular with Western's taste (Zaki 1987, 38). The weavers of the Safavid era, with the skills they possessed and according to the raw materials they had, made innovations in the technique of weaving and carpet weaving. The designs were transferred to the fabric and carpet texture with more elegance and beauty (Zaki 1987, 201). Yazd double gold fabrics and three-layer and multi-layer fabrics are also products of this time. Fabrics that had extra yarn in the fabric structure and their weaving history dates back to the Sassanid period, satin and velvet simple and textured are considered masterpieces of weaving in this period (Pope 2001, 2200). The Gurkani period of India, which coincides with the Safavid period in Iran, is considered to be the most brilliant artistic period in India. The culture-loving kings promoted the culture, literature and art of this land. The Mongol style of India was revived around 932 $\mathrm{AH}(1526 \mathrm{AD})$ by Babur in Transoxiana and continued until the time of Aurangzeb, the last Mongol prince in India (1707 AD). Fabric weaving is one of the most advanced and widespread industries among Muslim countries, including India, in terms of its many applications among all sections of society. The inhabitants of the Indus were among the pioneers of the art of weaving in the Islamic world. The fame of Muslim India textiles belongs to the eleventh to thirteenth centuries AH. The most important types of fabrics in the period of Gurkani are the fabrics of Calico, brocade (the most important examples of Gurkani brocade are named according to the design, motifs and consumption type of them to part of the Kimkhab brocade and Pot-tan brocade), Shawls and velvet.

\section{Research methodology}

The method of collecting information in this research is in the form of libraries, documents and samples of fabrics in libraries and museums which have been studied in field research. First, we collect the different fabrics of the two periods, and then we classify them based on arrays and patterns, and then we accommodate and compare these patterns, and we will examine the effect of these patterns on each other in the period. Fabrics from the Safavid and Gurkani periods, a review of works in the Victoria and Albert Museums in London, National Iran, Sheikh Safi al-Din Ardabili Astan, Washington DC Textiles, Boston Fine Arts, the Chicago Institute of Art, the Metropolitan of New York, and the United Kingdom and the available books in this field considered as Statistical population of this research. The method and tools of data analysis in this fiche method, image, book, computer and internet and museums.

\section{Data analysis}

In the classification of Safavid fabrics according to material, we can mention plant species: cotton and linen (rarely), animal: silk (the most important fibers of Safavid weaves), wool, goat hair, fur and lamb skin, minerals: gold, silver and other gold metals ( Forouzan Tabar 1382, 104). During this period, hunting scenes, images of animals, paradise gardens, trees and birds were engraved on Persian textiles, which were also popular in the Gurkanid court of India. Extensive relations between Iran and 
India in the 9th-11th centuries AH, 15-17 AD had a great impact on the textile trade and this trend was two-way. Tables 1 and 2 show the patterns of Safavid and Gurkani fabrics.

Table 1. The main and general designs of Safavid fabrics (Authors 2018)

\begin{tabular}{|c|c|c|c|c|c|}
\hline written & $\begin{array}{l}\text { The role of } \\
\text { Striped } \\
\text { Moharamat }\end{array}$ & Human motifs & $\begin{array}{l}\text { Geometric } \\
\text { patterns }\end{array}$ & $\begin{array}{l}\text { Animal motifs } \\
\text { (realistic, } \\
\text { abstractive } \\
\text { and } \\
\text { combined) }\end{array}$ & $\begin{array}{l}\text { Plant motifs } \\
\text { (abstractive } \\
\text { and realistic) }\end{array}$ \\
\hline $\begin{array}{l}\text { Inscriptions in } \\
\text { Naskh and } \\
\text { Nasta'liq } \\
\text { scripts }\end{array}$ & $\begin{array}{l}\text { The role of } \\
\text { paisley and } \\
\text { arabesque } \\
\text { flowers in } \\
\text { vertical rows }\end{array}$ & $\begin{array}{l}\text { More related } \\
\text { to the style of } \\
\text { Reza Abbasi } \\
\text { and the } \\
\text { Isfahan } \\
\text { academy }\end{array}$ & $\begin{array}{c}\text { More } \\
\text { Ghiasuddin } \\
\text { Naqshband } \\
\text { style to fill the } \\
\text { background }\end{array}$ & $\begin{array}{c}\text { Birds: } \\
\text { Sparrow, } \\
\text { Nightingale, } \\
\text { Peacock }\end{array}$ & $\begin{array}{l}\text { The image of } \\
\text { Persian } \\
\text { gardens and } \\
\text { trees: } \\
\text { sycamore, } \\
\text { cypress, } \\
\text { mulberry... }\end{array}$ \\
\hline $\begin{array}{c}\text { Designer and } \\
\text { weaver's } \\
\text { signature }\end{array}$ & & $\begin{array}{c}\text { Literary } \\
\text { subjects and } \\
\text { influenced by } \\
\text { drawings }\end{array}$ & $\begin{array}{l}\text { Layout or grid } \\
\text { (rhombic or } \\
\text { square grids } \\
\text { with plant or } \\
\text { animal motifs }\end{array}$ & $\begin{array}{l}\text { Animals: lion, } \\
\text { horse, deer }\end{array}$ & $\begin{array}{l}\text { Flowers: Rose, } \\
\text { tulip, iris, } \\
\text { jasmine } \\
\text { (flowers are } \\
\text { often } \\
\text { grouped) } \\
\text { Natural petals }\end{array}$ \\
\hline & & & & $\begin{array}{l}\text { Mythical } \\
\text { animals: } \\
\text { phoenix, } \\
\text { dragon and... }\end{array}$ & $\begin{array}{c}\text { Date leaves, } \\
\text { bergamot, } \\
\text { arabesque, } \\
\text { flowers and } \\
\text { vases }\end{array}$ \\
\hline
\end{tabular}

Table 2. The main and general motifs of Gurkani fabrics (Authors 2018)(

\begin{tabular}{|c|c|c|c|c|}
\hline written & geometric motifs & Human motifs & Animal motifs & Plant motifs \\
\hline & $\begin{array}{c}\text { Geometric grids } \\
\text { with plant motifs } \\
\text { (grid layout) }\end{array}$ & $\begin{array}{c}\text { Influenced by } \\
\text { Iranian painting } \\
\text { in banquets and } \\
\text { hunting }\end{array}$ & $\begin{array}{c}\text { The role of } \\
\text { elephant, cow, } \\
\text { deer }\end{array}$ & $\begin{array}{c}\text { Most floral } \\
\text { designs are } \\
\text { realistic. }\end{array}$ \\
\hline & $\begin{array}{c}\text { Integrating } \\
\text { Zigzag, rhombus, } \\
\text { mostly in the } \\
\text { margins }\end{array}$ & $\begin{array}{c}\text { hirds: Peacocks, } \\
\text { image of gardens } \\
\text { and animals }\end{array}$ & $\begin{array}{c}\text { flying birds, } \\
\text { flowers and } \\
\text { chickens }\end{array}$ & $\begin{array}{c}\text { Flowers and pots, } \\
\text { tree of life, } \\
\text { flower bushes } \\
\text { repeatedly in } \\
\text { each regular row }\end{array}$ \\
\hline
\end{tabular}

\section{4-1. Characteristics and methods of Safavid and Gurkani weaving}

In the first fabrics of the Safavid period, the garden scene was a very common visual theme. The Persian garden is usually enclosed behind a wall or hedge, and there are several types of shade trees such as sycamore, cypress, mulberry, etc. Most of the birds have sparrows, nightingales and peacocks and lions, horses and gazelles have been depicted on the fabrics (Valgrove 1374, 162). Subjects used in the design of Safavid fabrics include war stories, depicting humans at feasts and hunting, princes on horseback with their nobles, the use of writing in the decoration of fabrics, and the use of designs of flowers, animals, and humans. Among them, the themes of the Sassanid period have also been used. Also, the designers of the Safavid period in decorating the fabrics have been more inspired by Iranian 
myths and literature such as Shahnameh and Khamseh Nezami (Baker 2006, 127). In India, the weavers were woven with raw silk, most of which was woven in the Indian city of Surat. The design of fabrics is fine, bushy, hunting ground and so on. In banares, it was made with a special blue and silver fibers and silversmith design with the design of paisley. During the Mongol era, all of this changed and plant and flower subjects became more naturalistic. In the 16th century, Persian floral motifs replaced old motifs. In the period of Akbar Shah, semi-blossomed flowers were depicted, in Jahangir era, fully blossomed flowers and in the time of Shah Jahan, small blossoms were depicted with emphasis on leaves (Blair $2012,172)$.

\section{4-1-1. Analytical comparison of Iranian and Indian calligraphic works}

Iranian artistic styles in the Islamic period are completely decorative. Decoration in Islamic art is manifested in the form of calligraphy, the use of various motifs such as plant motifs and geometric motifs. Examining and comparing the designs of calligraphic fabrics with other Iranian arts shows that there are similarities between the designs of calligraphic fabrics, carpets, tiles and to some extent plastering and carving on wood. Probably the designers of Ghalamkars, carpet and tile designs created new designs by using the designs and patterns used in these artistic industries and combining them together (Ehsani 1350, 1). Prominent works of the influence of Iranian art on Indian textiles can also be seen in its Ghalamkars. At that time, the closeness of the two royal families in Iran and India led to a close artistic connection that created innovations and inventions in the production of various textiles. Comparing the examples of Indian calligraphy with Iranian examples, it can be seen that Indian artists and craftsmen have used a new artistic language in their works by adapting Iranian works, which can be examined from two aspects: decorative arrays used in calligraphy and composition, and Combining Ghalamkar designs (Table 3).

Table 3. Motifs and uses of Iranian and Indian Ghalamkars (Authors 2018)

\begin{tabular}{|c|c|c|}
\hline Ghalamkar uses & Decorative arrays & $\begin{array}{c}\text { General } \\
\text { design }\end{array}$ \\
\hline Bracket, curtain & geometrical & Altar \\
\hline Carpet, back cover, seat cover & plants & $\begin{array}{c}\text { Medallion } \\
\text { corner }\end{array}$ \\
\hline cloth & animal & Tree of life \\
\hline Prayer carpet & written & $\begin{array}{c}\text { Hunting } \\
\text { ground }\end{array}$ \\
\hline & - & $\begin{array}{c}\text { Sriped } \\
\text { Moharramat }\end{array}$ \\
\hline & & pictorial \\
\hline
\end{tabular}

\section{4-1-2. Analytical comparison of Indian and Safavid brocade designs}

Throughout history, Iran and India have had constant relations with each other. Their influence on each other's art and culture in different historical periods, especially in the Gurkani period of India, has been expressed by various scholars. The kings of India strongly supported the migration of Iranians and always encouraged the presence of Iranian elites in the Indian court (Ershad 1379, 201) and (Fariyeh $1374,168)$. During the Islamic period, the Mongols of India paid attention to the artistic and cultural fields of Iran, and with the migration of a number of Iranian craftsmen, artists and weavers to the Gurkani court, the art of Indian textile weaving flourished. For example, 4,000 silk weavers worked in the Sultan's workshop in Delhi, and the methods and designs they presented influenced on Indian weaving. India, which was able to attract various artistic methods, quickly became a producer of gold cloth, one of the most delicate Indian textiles, and the Iranian gold weaving method spread in its textile centers (Harris 2006, 111). The Indian brocades were made under the supporting of the court and were 
decorated with adaptations of Persian and Indian elements. The culture and art of the Avada Shiite Muslims, who were of Iranian descent, were also influenced by the Safavid court. In their weaves, they used images such as hunting scenes and plant designs that were common in Iran, and their clothes were also influenced by the Iranians (Agraval 1382, 109). In the design of Gurkani brocade fabrics, which were produced under the influence of Safavid brocade, common decorative motifs can be observed. Influenced by Safavid art in India, Iranian designs appeared in Gurkani's brocades. Indian artists have adapted Iranian motifs and designs based on indigenous artistic traditions and used them to decorate textiles. Also, the weavers of gold fabrics, relying on their innate taste and talent while weaving the fabric, have made changes in its common designs, which eventually led to a kind of creativity and innovation in patterns and created original and beautiful designs on the fabrics (Table 4). . Various decorative motifs have been used to create brocades, the decorative themes of which can be divided into five groups: motifs of flowers and trees, animals and birds, humans, lines and geometric shapes. These motifs can be seen realistically or abstractly or as a combination of both in various forms on fabrics: plants and trees, animals, human figures, the use of calligraphy and geometric shapes.

Table 4. Brocade fabric in Safavid Iran and Gurkani period India (Authors 2018)

\begin{tabular}{|c|c|c|c|c|c|}
\hline $\begin{array}{c}\text { The most } \\
\text { important } \\
\text { Iranian } \\
\text { brocades }\end{array}$ & $\begin{array}{c}\text { The most } \\
\text { important } \\
\text { Indian } \\
\text { brocades }\end{array}$ & Uses In Iran & Uses in India & $\begin{array}{c}\text { Decorative } \\
\text { elements }\end{array}$ & Design(brocade) \\
\hline $\begin{array}{c}\text { ikat } \\
\text { Brocade }\end{array}$ & Kimkhab & Court use & Court use & $\begin{array}{c}\text { Flowers and } \\
\text { plants }\end{array}$ & Patterns \\
\hline Satin brocade & Pot-tan & Daily uses & $\begin{array}{c}\text { Celebrations, } \\
\text { feasts and } \\
\text { religious } \\
\text { ceremonies }\end{array}$ & panimals & pictorial \\
\hline $\begin{array}{c}\text { Lampas- } \\
\text { woven }\end{array}$ & $-\begin{array}{c}\text { Quran cover, } \\
\text { curtain, } \\
\text { cushion, } \\
\text { bracket }\end{array}$ & $\begin{array}{c}\text { Animal cover } \\
\text { (horse } \\
\text { saddle, } \\
\text { elephant) }\end{array}$ & birds & stripes \\
\hline- & $\begin{array}{c}\text { Furnish the } \\
\text { King's Path }\end{array}$ & $\begin{array}{c}\text { Religious } \\
\text { places }\end{array}$ & human & Medallion corner \\
\hline- & saddle & - & $\begin{array}{c}\text { Geometrical } \\
\text { shapes }\end{array}$ & written \\
\hline
\end{tabular}

\section{4-2. Comparative study of Safavid and Gurkani patterns}

The fabrics of the two periods are studied on the basis of color, design and motifs, and their commonalities and differences are examined together.

\section{4-2-1. Plant motifs}

This group occupies a large part of the designs used in Safavid and Gurkani fabrics with a wide variety. Various flowers of tulips, Dog-rose, lotus, iris, paisley, as well as various types of Shah Abbasi flowers that were used by artists during this period. Most of these fabrics were made to order by the courts of the two governments. Velvet and silk gold were used in a variety of court fabrics such as curtains, tombstones and tablecloths. A comparative study has been performed on several pairs of fabrics similar to Safavid and Gurkani, whose similarities in role are easily recognizable. The first example examined here is a valuable pair of surviving Safavid overcoats, one of the lint velvet with beige 
background, and the youthful motifs of the alternate with a flowering plant. Beige or cream background can be seen on Iranian fabrics, which has a pleasant warmth with the colors of the same family, such as orange and brown, etc. It was necessary to use the colors of the whole family to create more delicate motifs. The method of designing the human role in this overcoat is influenced by the design in the paintings of Reza Abbasi School, and thus the relationship between the designs of the Safavid fabrics and painting can be clearly seen. The most important factor in the formation of Safavid textiles is the power of the combination of designers in creating cohesive works. Safavid designers had great ability in combining human design (Figure 2). A similar example of a Gurkani overcoat belongs to the reign of Jahangir, on which designs are embroidered with fine stitches of Gujarati artists. The soft colors and its family show the influence of Iranian art, but nature, plants and animals have a very realistic performance that is specific to the Indians, and also does not show any image of man who played a major role in the two above-mentioned Iranian examples. And a margin of flowers and arabesque motif is embroidered on its edge (Gharavi 1385, 168) (Figure 3). By observing the designs used in the two mentioned examples, the effect of Safavid fabrics on Gurkani weavings can be clearly seen. The whole of this ceremonial dress is covered with plant and animal motifs. These two examples have significant similarities to each other. Due to the influence of cultures and the continuation of the naturalism of Gurkani art, Islamic patterns can also be seen in Gurkani woven fabrics. An example of this is a fabric belonging to the Shah Jahan era, which is made of wool, fluff and silk. The background of this fabric is lacquered red and its pattern is a lattice design that in each unit, the motifs of Shah Abbasi flower and other flowers are placed among the arabesque motifs. Of course, the arabesque used in the sample of Safavid fabric has a more naturalistic form and in the sample of Islamic Gurkani fabric, it has an abstract state (Figure 4). The use of Shah Abbasi flowers next to the leaves can be seen in the royal velvet silk tent belonging to Shah Tahmasb's rule in the 1540s. This fabric, which has a cream-colored background and a lattice pattern, is connected to each unit with spotted ribbons, two buds, two multi-colored red flowers with ivy, and inside them are the flowers of Shah Abbasi. The colors used in this piece are dark-blue, red, cream, and Beige (Figure 5).

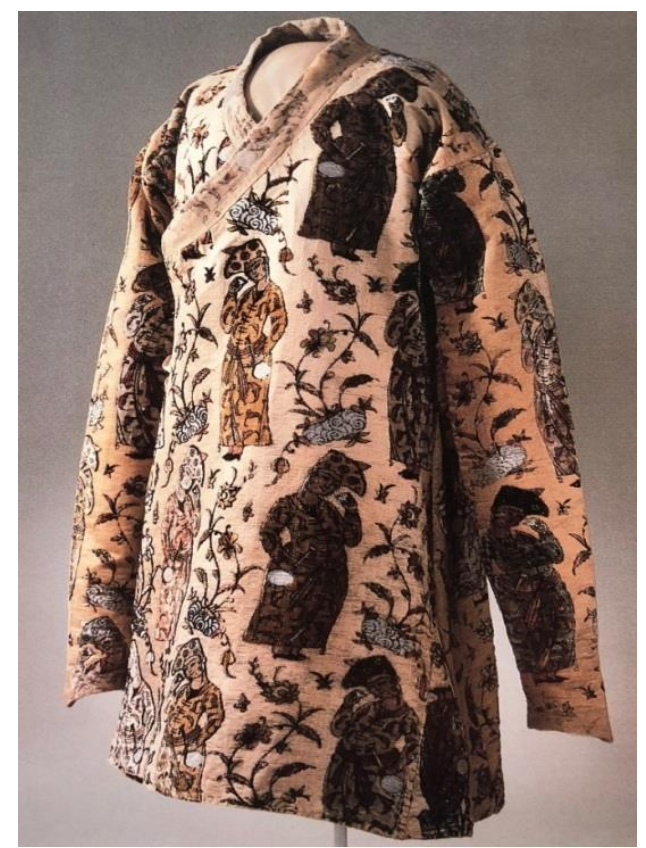

Figure 2. Silk velvet coat, 17 AD-11 AH, Safavid, Iran. (Harris 1372, 83). 


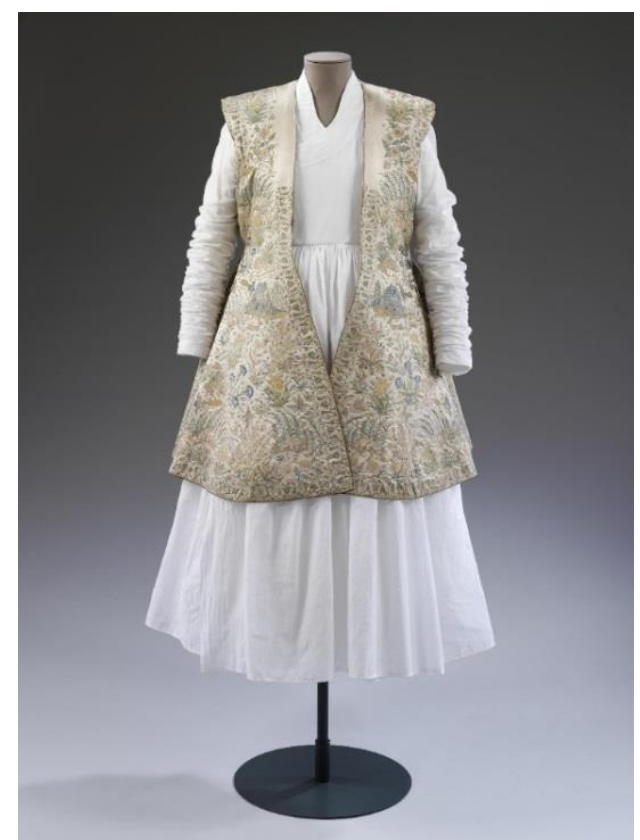

Figure 3. Jahangir Shah overcoat, for hunting, 1630-1620 AD / 1030-1040 AH, Victoria and Albert Museum London (www.vam.ac.uk)

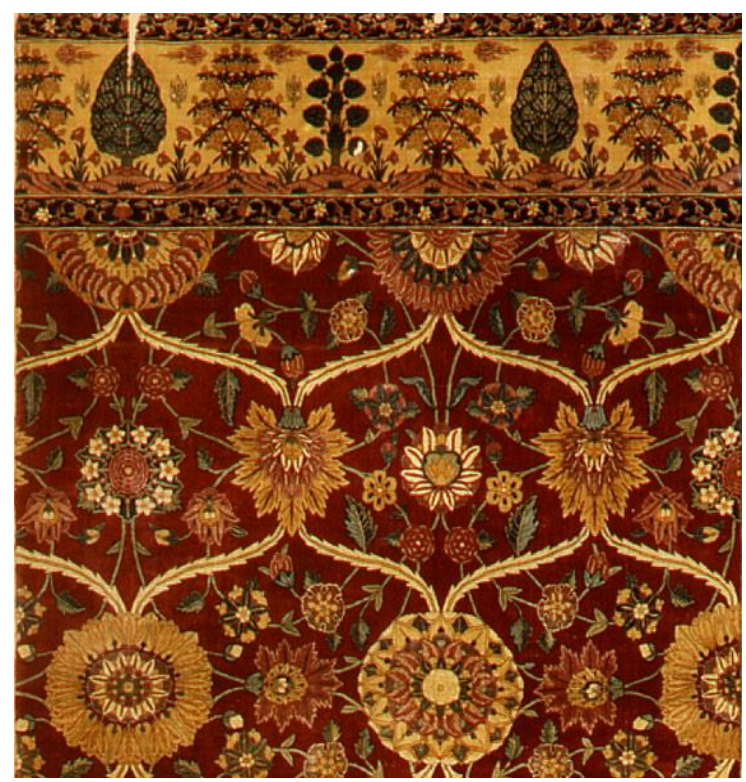

Figure 4. Fabric with the design of Shah Abbasi and Islamic flowers, India, 1650 AD - 11 AH, Metropolitan Museum. (www.metmuseum.org) 


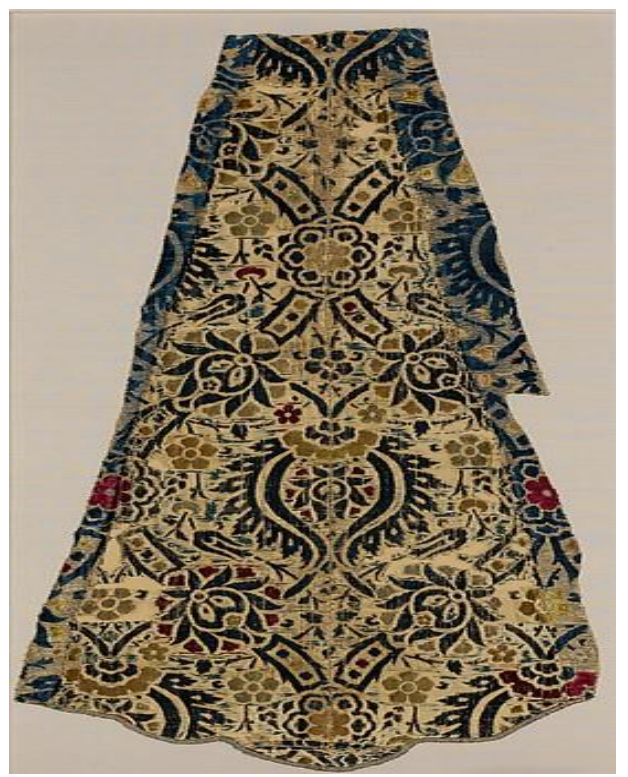

Figure 5. A piece of velvet silk fabric with the design of Shah Abbasi and Islamic, 1540 AD, 10 AH, Metropolitan Museum (www.metmuseum.org)

\section{4-2-2. Human and animal motifs}

This group of motifs includes landscapes of Iranian martial and festive stories such as the Shahnameh and military works, images of Iranian greats hunting or the feast of the hunters, images of hunters with hunting tools, or predatory fighting animals. The molded clothes of the people in such images are among the luxurious and special clothes of the courtiers. From the end of the ninth century-fifteenth century $A D$, there is a great interest in the visual aspect and the role of the figure (Talebpour 1388, 135). Among the specimens obtained from this group are velvet fabrics with metal threads belonging to the 10th century AH - 16 AD, which are kept in the Maki complex. The design of this image has a lattice shape and inside the frames, the image (medallions) of two people can be seen next to the tree. In one case, one of them has a luxurious dress with a hat in the style of Qizilbash and a bird which is a hawk sitting on his hand and the other in the costume of his attendants. This example shows an image of an open hawk or someone who hunts. The type of cover and postures of these two people are taken from Safavid period paintings which are decorated with flower and plant patterns between the frames (Figure 6). The textiles of the Safavid period show the technical mastery of the weavers and also their strong dependence on the illustration and lighting of the book as a source of pattern for the design of the textiles in the court workshops. Another example that the effect of painting on the patterns can be seen well is the silk fabrics belong to the middle of the tenth century - sixteenth century AD. The designs on the crocheted fabrics and the patterns show the majestic banquet hall. In the center of the image is a magnificent garden with countless trees, a pond and lake stream water, in the upper part of which a person sitting on a bed can be seen with his attendants around the bed. The type of clothing worn by people in luxurious clothes and Qizilbash hats, as well as the overall composition of this work, is very similar to the paintings of the Safavid period. The role of Simurgh and the dragon in the triangle part of the center of the cloth and other mythical animals woven in a small margin, suggests that it may be an adaptation of Shahnameh stories (Kanbay 1381, 57) (Figure 7). In another similar example in Gurkani fabric, we see the effect of Safavid weaving, calico cotton fabric with the design of human beings feasting in a magnificent garden with many trees, there is also a hunting scene. Plant and tree motifs are scattered throughout the fabric, and animals such as goats, lions and deer, birds and peacocks can be seen. The motif and design of this fabric are also influenced by the fabrics of the Safavid era, the motifs of feasts and people in the service of the king and rejoicing and playing the 
musical instrument and the type of all composition indicate the effect of designs used in the Safavid era on Gurkani examples. Court women with the usual coverings of that period are also present in this fabric, which are also very close to the designs of Safavid women. The colors used in this fabric are red, yellow, green and acre, brown (Figure 8).

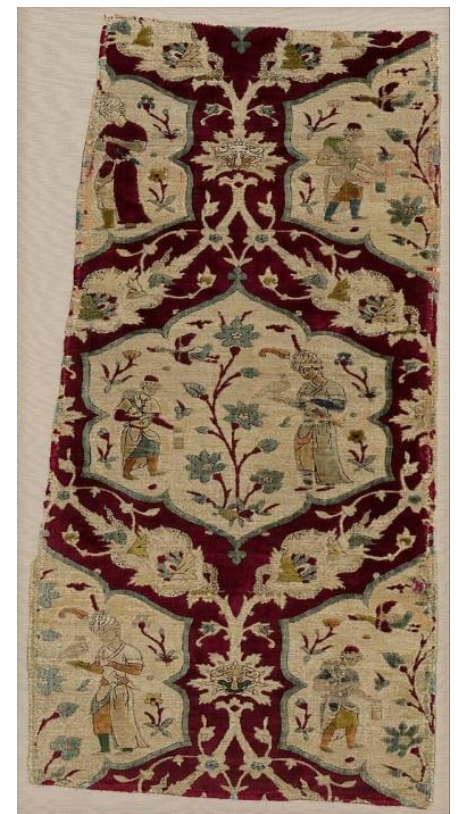

Figure 6. A piece of velvet fabric with a human design, $16-10 \mathrm{AH}$, Iran, Metropolitan Museum (www.metmuseum.org)

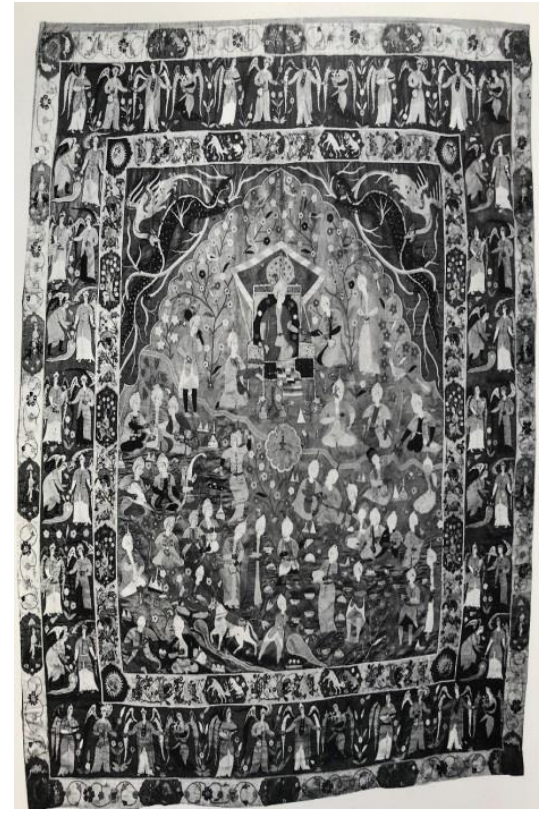

Figure 7. Silk with the design of the feast scene, Iran, Tabriz, 10th century AH - 16 AD. (Harris 1374, 84) 


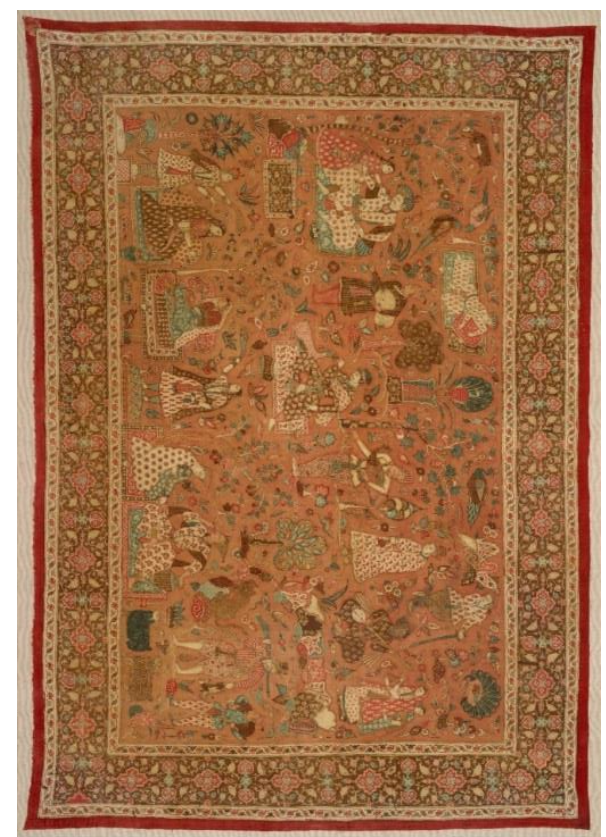

Figure 8. Curtain, calico cloth, flower stamp, scene from court life, 1650 -11 AH, Metropolitan Museum (www.metmuseum.org)

\section{4-2-3. Calligraphic decorations}

Decorating fabrics and writing by Naskh, Nastaliq and Thuluth scripts is one of the decorative methods that became common during the Safavid period. The inscriptions were mostly used to decorate tombstones, curtains or to cover sacred places. The writings were often designed symmetrically; Sometimes Quranic verses, supplications, hadiths and poems and sometimes the name of the weaver were woven in the fabric (Talibpour 1388, 134). The first example of this group is gold cloth with an inscription belonging to the 11th century AH - 17 AD, from Isfahan, which was used to cover the grave and is now kept in the National Museum of Iran. The background of this fabric is golden and decorated with the cross medallion pattern. Inside the medallion, verses 1 to 3 of Surah An-Nasr are repeatedly woven in the Nasta'liq script. In the Safavid period, verses from the Qur'an and prayers were usually written on cloths used in tombs or in religious ceremonies (Talibpour 1388, 54) (Figure 9). Another example of Safavid fabrics with calligraphy and plants, made of Yazd gold fabric belonging to the 11th century AH - 17 AD, is kept in the National Museum of Iran. This cloth is also used in covering the grave and on the margin of it, the prayer of blessings on the fourteen infallible is woven in Jeli Thulut and the text of this cloth is decorated with the design of the altar. The word Surah Al-Fatihah is written. The background of the fabric has flower and plant motifs and inside the flowers of Shah Abbasi, the name of its weaver, Ghias Naqshband, is woven in Kufic script (Ruhfar 1378, 59-60) (Figure 10). In the Safavid period, calligraphy on cloth, either in the form of weaving on cloth or by the method of printing by wooden stamps, was common, which is known as etching. In the National Museum of Iran, a linen cloth has been displayed, which has been written with Quranic verses in Kufic script, Thuluth, Naskh and Ghobar with lapis lazuli pigment, vermilion, gold and saffron. This masterpiece was created by the famous calligrapher Yousef Al-Ghobari for the vow of Abu al-Fath Mirza Shah Ismail Safavid with the intention of dedicating it to the Astane of his great ancestor Sheikh Safi al-Din Ardabili (Figure 11). 


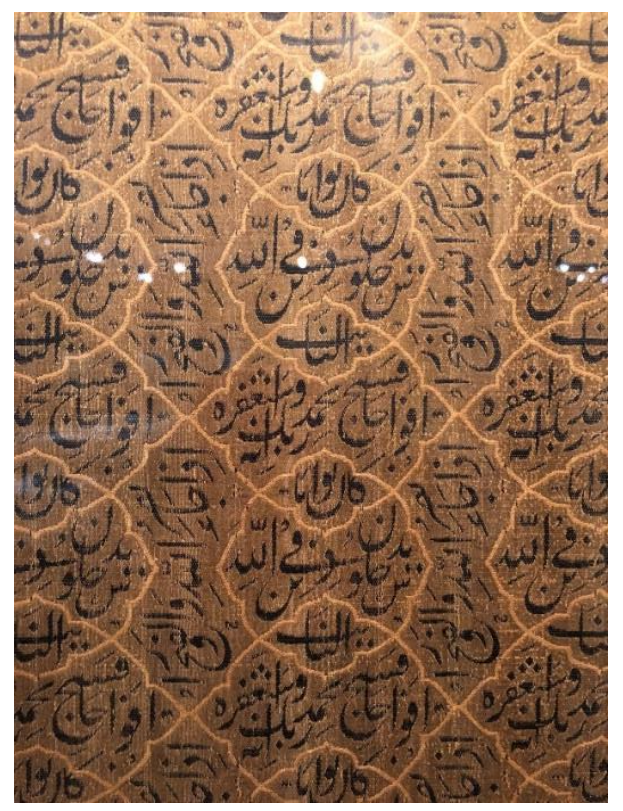

Figure 9. Knitted fabric, tomb cover, 11th century AH, 17 AD, National Museum of Iran (Authors 2017)

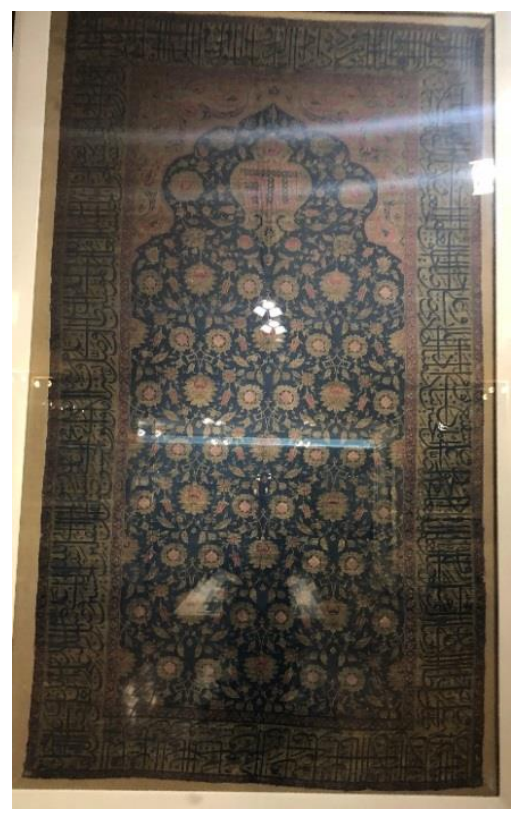

Figure 10. Tomb cover, the design of an altar with a thousand flowers, inscription in Kufic script and third, Yazd, 11 AH -17 AD, National Museum of Iran (Writers 2017) 


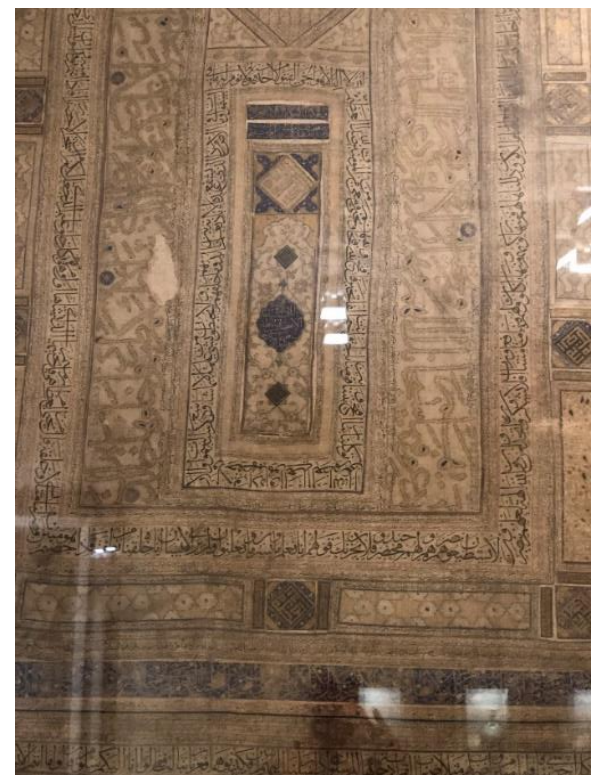

Figure 11. Linen cloth in Kufic script, Naskh, Thuluth, Ghobar of 945 AH-1539 AD, National Museum of Iran (Authors 2017)

\section{4-3. Statistical studies}

Iranians and Indians have been related to each other since ancient era and have common racial and historical roots. The studied centuries are almost the peak period of two great Islamic dynasties, namely Safavid and Gurkani, which these two great eastern neighbors with a long history of civilization and religious commonalities of Islam, have engaged in great cultural and artistic exchanges. The motifs also differ in terms of tools, methods, as well as aesthetics and historical, mythological, religious, etc. Common Safavid and Gurkani textiles are various types of etching, brocade, shawls and velvet. Figures 1 to 4 show a comparison of volume, color, patterns, and common designs.

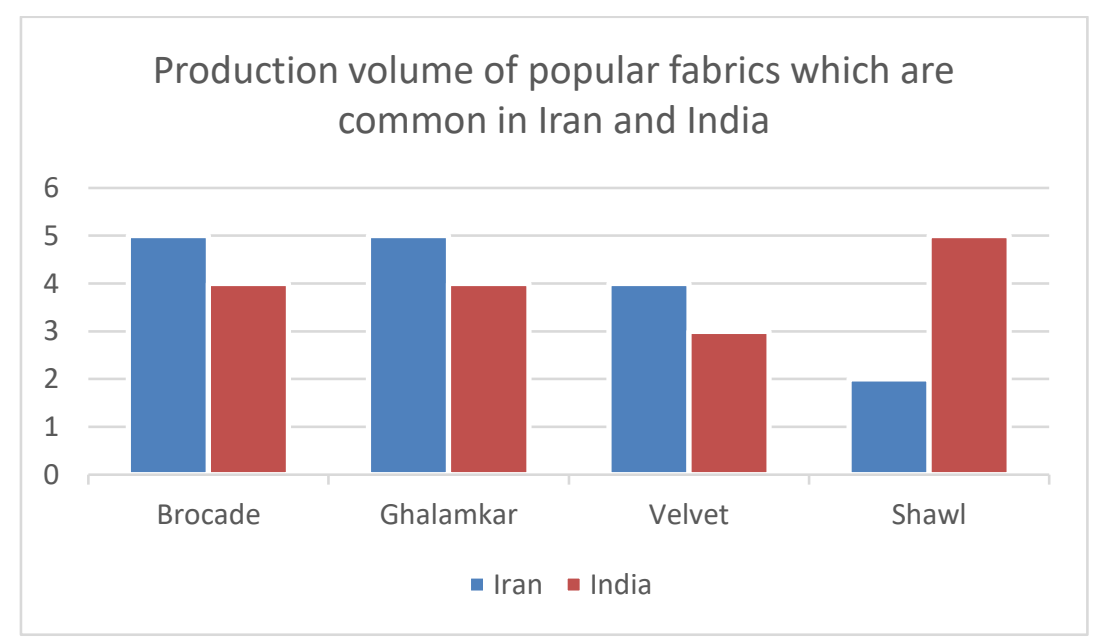

Figure 1 . Production volume of popular fabrics which are common in Iran and India (10-12 AH, 15-17 AD) (Authors 2018) 


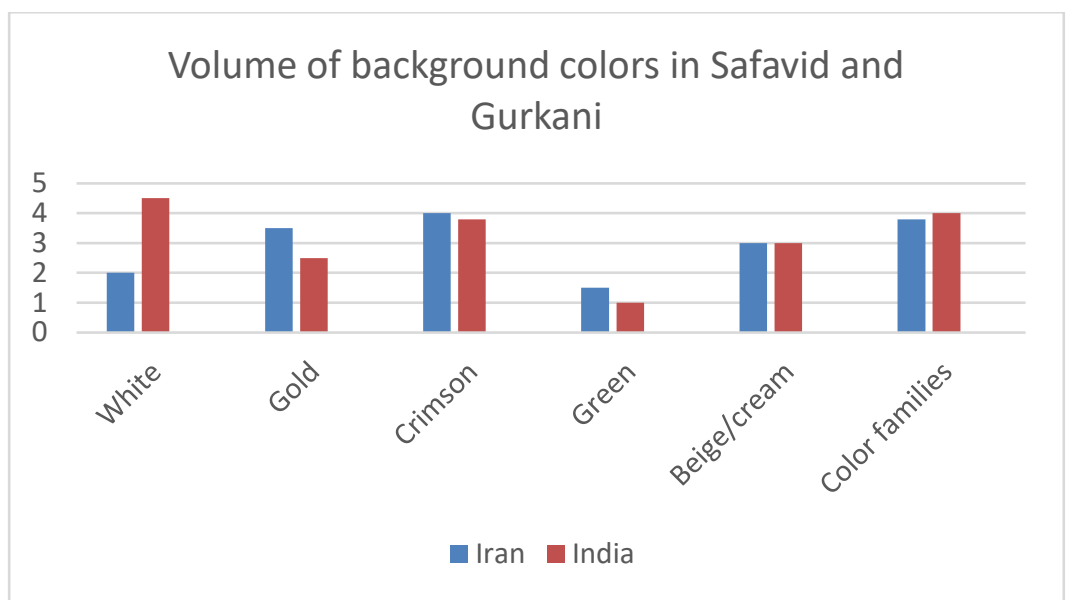

Figure 2. Volume of background colors in Safavid and Gurkani fabrics (10-12 AH, 15-17 AD) (Authors 2018)

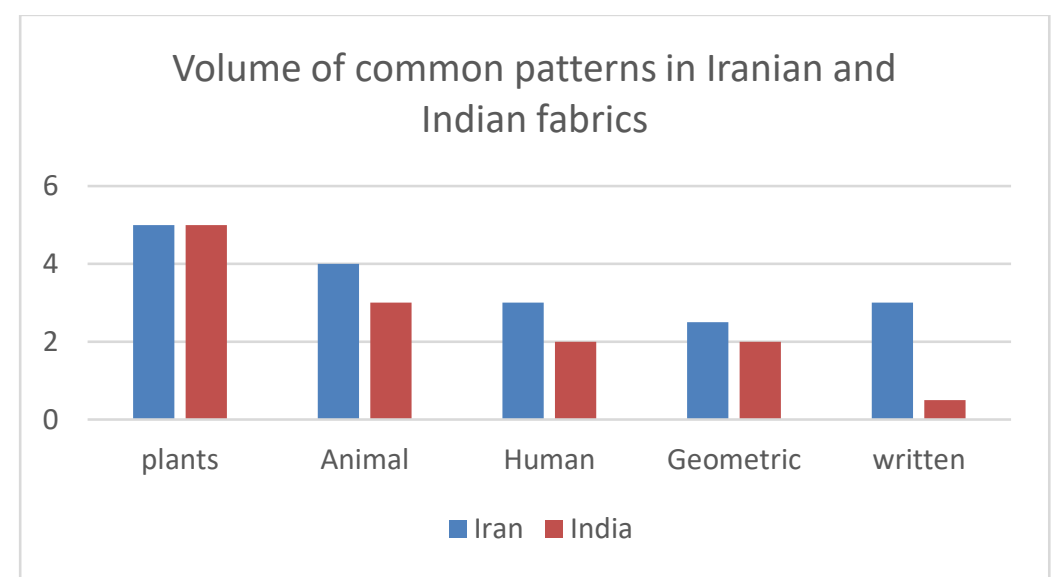

Figure 3. Volume of common patterns in Iranian and Indian fabrics (10-12 AH, 15-17 AD) (Authors 2018)

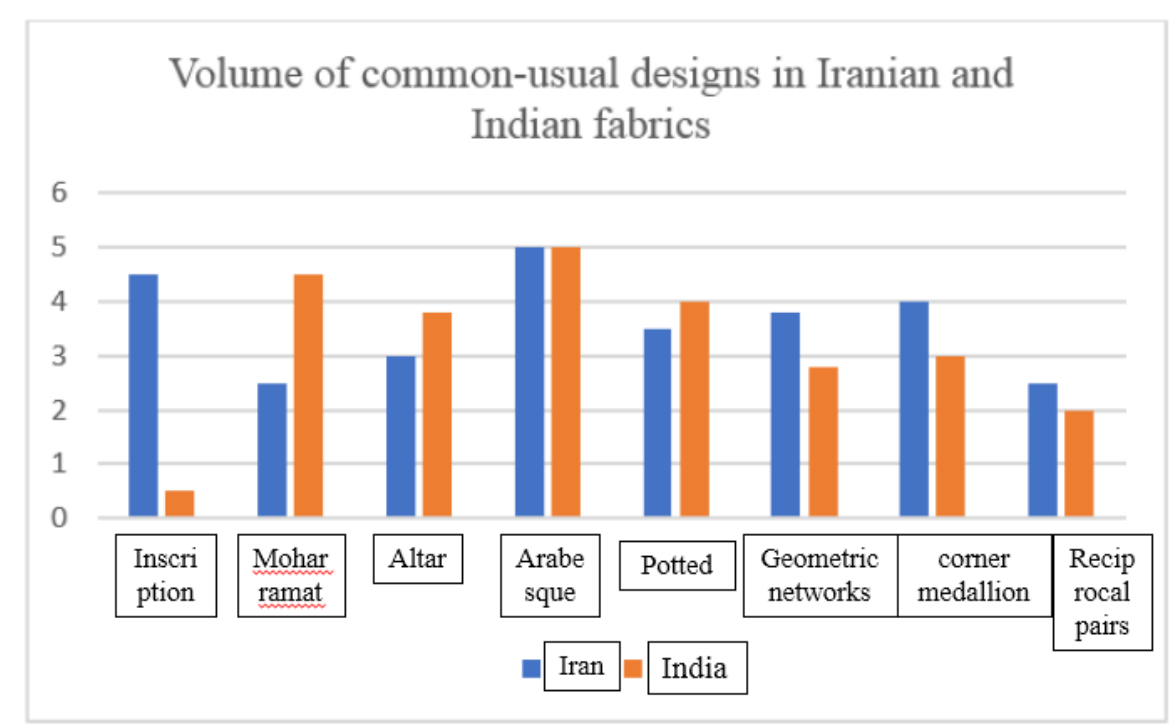

Figure 4. Volume of common designs in Iranian and Indian fabrics (10-12 AH, 15-17 AD)

(Authors 2018) 


\section{Conclusion}

Fabrics with simple motifs or court motifs were all common consumer goods in the two periods. Extensive communication between Iran and India and trade between them and the migration of Iranian artists had a significant impact on the design of textile patterns, and this has been a two-way process. Differences in designs and motifs depended considerably on the material, tools, art, as well as aesthetics and historical, mythological, and religious influences. Different colors were commercial products between the two countries, which were used in different ways, considering that pigments were available and with different theories. The most important reason for the comparative study of Iranian and Indian textile patterns is to know more and better the design of patterns in order to understand the historical origin and how to design and preserve them throughout history and change and destroy them. This research has been a good process to understand the credibility and history of this industry. As a result, such a study required the study of patterns and the textile industry of the two dynasties separately and a comparative comparison of their patterns. For this purpose, the patterns of the fabrics in each period were studied and categorized separately. In order to study the commonalities and differences in this industry between Iran and India and their effect on each other was examined. In these studies, we conclude that the designs of Safavid textiles are defined by the characteristic of tendency to naturalism and dynamism, free combination with the motifs of natural landscapes, decorative. However, in comparison with Gurkani fabrics, the tendency to abstraction and geometric shapes is more symmetrical composition with decorative frames. The designs of the Gurkani textiles were more realistic and did not follow a particular composition and symmetry in landscapes with a human role. The tendency to show plant motifs is seen more than any other role in its types of textiles, and of course, plant motifs are mostly used in the fabrics of the two lands. The naturalistic design of plants and living things and the bright colors of the background are all prominent features of Indian art. In the Safavid period, the maps were more narrative in order to be seen as a separate element. Narratives such as love stories, mysticism, scenes of hunting and war, as well as calligraphy in the form of prayers, signatures, Quranic verses, have been used as one of the most important features of Islamic art. Due to the great influence of Iranian textiles, we do not see so much narrative in Gurkani fabrics. In the Gurkani period, due to the fact that the artistic styles in Iran's Islamic period are completely decorative, the motifs take on a more material aspect.

\section{References}

Ackerman, P., \& Arthur P. (2008). A tour of Iranian art from prehistoric times to the present day. Translated by Najaf Daryabandari and others. Tehran: Scientific and Cultural Publications.

Agrawal, Y. (2003). Silk Brocade. Lustre press. Rooli Books. New Delhi, India.

Baker, P. (2006). Islamic Textiles. Translated by Mahnaz Shayestehfar. Tehran: Institute of Islamic Art Studies.

Blair, S., \& Jonathan, U. B. (2012). Islamic Art and Architecture. Translated by Ardeshir Ishraqi. Tehran: Soroush.

Chit Saz, M. R. (2001). History of Iranian clothing. Tehran: Side.

Ehsani, A. H. (1972). Iranian etching Collection. Tehran: National Bank of Iran. 
Forouzan Tabar, H. (2003). Safavid Fabrics. Art Quarterly. Iranian Arts. Translated by Parviz Marzban. Tehran: Farzan.

Gharavi, M. (2006). The Magic of Color (Introduction to the Artistic Relations between Iran and India). Tehran: Ministry of Culture and Islamic Guidance.

Guidance, culture. (2000). Historical migration of Iranians to India. Tehran: Institute of Cultural Studies and Research.

Harris, J. (1993). 5000 Years of Textiles. British Museum Press. London.

Kenbay, S. (2002). Iranian Painting. Translated by Mahnaz shayeste faf. Tehran: Institute of Islamic Art Studies.

Pope, A. (2001). Masterpieces of Iranian Art. Translated by Parviz Natel Khanlari. Tehran: Scientific and cultural.

Pope, A. (2002). Familiarity with Iranian miniatures. Translated by Hassan Nayr. Tehran: Art and bahar Book Publishing Center.

Ravandi, M. (1963). Social History of Iran, Volume 1, Tehran. Amir Kabir.

Rice, T. (2002). Islamic Art. Spring King Month Translation, Tehran: Scientific and Cultural Publications.

Roh Far, V. (1999). Zarifafafi in the Safavid period. Book of the Month of Art. Nos. 17 and 18.

Talibpour, F. (2010). The Influence of Iranian Patterns on the Art of Indian Engraving. Journal of Fine Arts - Visual Arts. Issue 39.

Walgrove, D. (1995). Textile of Iranian Arts. Under the supervision of R. W. Frey. Translated by Parviz Marzban, Tehran: Farzan Day Research

Wilson, J. C. (1938). History of Iranian industries. Translated by Abdullah Faryar. Tehran, Farhangsara. Yavari, H. \& Others. (2006). Esfahan. Tehran: Academy of Arts.

Zaki, M. H. (1987). History of Iranian Industries after Islam. Translated by Mohammad Ali Khalili. Tehran: Iqbal.

Ziapur, J. (1964). Ancient Iranian clothing from the earliest times to the end of the Sassanid Empire. General Administration of Museums. Tehran: Popular Culture. 